\title{
PERUBAHAN VOLUME TUMOR POST-RADIASI EKSTERNA PADA PASIEN KANKER NASOFARING
}

\author{
Aidilawarti K. S. ${ }^{1)}$, Guntur Winarno ${ }^{2)}$, Asumsie Tarigan ${ }^{2)}$, Moh. Haris ${ }^{3)}$ \\ ${ }^{1)}$ Radiografer RS Eka Hospital Pekabaru Riau \\ ${ }^{2)}$ Dosen Jurusan Teknik Radiodiagnostik dan Radioterapi, Politeknik Kesehatan Kementerian Kesehatan Jakarta II \\ Kebayoran Baru, Jakarta Selatan 12120 \\ ${ }^{3)}$ Radioterapis Instalasi Radioterapi Rumah Sakit Pusat Kanker Nasional Dharmais, Slipi, Jakarta Barat 11420
}

Email : aidilawartiks@yahoo.com

\begin{abstract}
Introduction: The radiotherapists provides fractional treatment effectively and efficiently. The expected radiation response can be achieved for tumor volume change so that the principle in radiotherapy is to kill as many cancer cells as possible. However, due to the prognostic factors that may affect the radiation response such as Epstein-Barr Virus, TNM stage system, primary tumor, patient age, sex, type of treatment, and histopathology.

Objective: This study is intended to analyze changes in the volume of external post-radiation tumors in nasopharyngeal cancer patients.

Methods: This study is a descriptive quantitative study to determine changes in tumor volume from proradiation to post-radiation in patients with nasopharyngeal cancer. The sample used was the secondary data which belongs to Radiotherapy Installation at Dharmais Cancer Hospital Jakarta in patients with nasopharyngeal cancer in 2017. The study sample was taken on subjects who meet the criteria of inclusion and exclusion.

Results: From the 51 study samples, the results are obtained based on stages, post-radiation tumor volume changes from stage II, III, and IV by $206.56643 \mathrm{cc}, 135.81397 \mathrm{cc}$, and $168.83302 \mathrm{cc}$. By sex, postradiation tumor volume changes of male and female sexes were 174,18946cc and 176,02196cc. By age, post-radiation tumor volume changes in the age group 20-39 years, 40-49 years and $>50$ years of $183.42215 \mathrm{cc}, 175.36875 \mathrm{cc}$, and $166.95548 \mathrm{cc}$.

Conclusion: It can be concluded that the largest tumor volume change which leads to radiation effectiveness and better prognosis based on stage is at stage II, based on sex is on female gender, and by age was in the age group of 20-39 years.
\end{abstract}

Keywords: Tumor volume change, Post-radiation, Nasopharyngeal cancer

\section{Pendahuluan}

Kanker nasofaring bersifat radiosensitif (Kentjono WA et al, 2003) sehingga radioterapi selalu menjadi pilihan pengobatan utama untuk mematikan semua sel kanker di nasofaring (Nurmasari S et. al, 2007 dan Lo KW et al 2004). Di Indonesia, kanker nasofaring termasuk kanker tertinggi di regio kepala dan leher (Muin A, et a1, 2009 dan Brillian Putri E, et al, 2011) dengan laki-laki 2-3 kali lebih sering terkena dari pada perempuan (Rahman S, et al, 2015). Kanker nasofaring sebagian besar ditemukan pada pasien yang berusia di atas 20 tahun, yaitu antara 50-70 tahun dan paling banyak pada usia produktif yaitu antara 30-59 tahun dengan puncak antara 40-49 tahun, dan tidak ada peningkatan setelah usia 60 tahun (Brillian Putri E, et al, 2011).

Untuk stadium awal, tumor hanya menimbulkan gejala yang tidak khas dan tidak spesifik ((Muin A, et a1, 2009 dan Christanti J, 2011) karena terletak di daerah yang sulit dilihat dari luar dan sering tidak dikenali karena keluhan yang sangat umum (Brillian Putri E, et al, 2011) namun dalam stadium ini peran radioterapi sangat baik (Kentjono WA et al, 2003). Akan tetapi, apabila diagnosis terlambat (Ayu D, et al, 2015) dan muncul benjolan pada kelenjar leher ( Kurniawati D, et al, 2013 dan Faiza S, et al, 
2013) diperlukan kombinasi dengan kemoterapi untuk stadium lanjut (Lo KW et al 2004, Wang W, et al, 2016 dan Yarbro CH, et al, 2011) baik dengan kemoterapi neoadjuvan maupun concurrent (Lo KW et al 2004 dan Liu L, et al, 2015).

Kanker nasofaring juga menunjukkan hubungan kuat dengan virus Epstein-Barr (Lo KW et al 2004 dan Liu L, et al, 2015) sebagai salah satu faktor prognostik yang memainkan peran penting dalam mengubah sel epitel nasofaring menjadi kanker invasif. Faktor prognostik lain yang sangat mempengaruhi respon terhadap radiasi adalah sistem stadium TNM, tumor primer, usia penderita, jenis kelamin, jenis pengobatan, dan histopatologi (Lo KW et al 2004 dan Liu L, et al, 2015).

Pemberian dosis yang optimal hingga mencapai dosis total ditetapkan dengan sistem fraksinasi. Tugas radioterapis memberikan treatment secara fraksinasi dengan efektif dan efisien diharapkan respon radiasi dapat dicapai untuk perubahan volume tumor sehingga prinsip dalam radioterapi untuk mematikan sebanyak mungkin sel kanker terpenuhi ( Rosita I, et al, 2017). Namun dikarenakan adanya faktor prognostik yang dapat mempengaruhi respon radiasi, peneliti ingin menganalisis perubahan volume tumor post-radiasi eksterna pada pasien kanker nasofaring di Instalasi Radioterapi Rumah Sakit Kanker Dharmais.

\section{Metode}

Penelitian ini adalah penelitian kuantitatif deskriptif untuk mengetahui perubahan volume tumor dari pro-radiasi sampai post-radiasi eksterna pada pasien kanker nasofaring.

Pengolahan dan analisis data dari penelitian ini adalah membuat deskripsi pasien berdasarkan faktor prognostik yaitu stadium, jenis kelamin, dan usia dengan perubahan volume tumor. Setelah mendeskripsikan perubahan volume tumor berdasarkan faktor prognostik, lalu menentukan klasifikasi kemungkinan respon tumor terhadap radiasi

\section{Hasil dan Pembahasan}

Karakteristik sampel penelitian dilihat dari faktor prognostik pada pasien kanker nasofaring meliputi stadium, jenis kelamin, dan usia. Distribusi sampel berdasarkan faktor prognostik dapat dilihat pada Tabel 1 berikut.
Tabel 1. Distribusi Sampel Penelitian

\begin{tabular}{|c|c|c|}
\hline Karakteristik & Jumlah & $\%$ \\
\hline \multicolumn{3}{|l|}{ Stadium } \\
\hline 1. Stadium II & 15 & 29,41 \\
\hline 2. Stadium III & 10 & 19,61 \\
\hline 3. Stadium IV & $\begin{array}{c}26 \\
(\mathrm{n}=51)\end{array}$ & 50,98 \\
\hline \multicolumn{3}{|l|}{ Jenis Kelamin } \\
\hline 1. Laki-laki & 32 & 62,75 \\
\hline 2. Perempuan & $\begin{array}{c}19 \\
(\mathrm{n}=51)\end{array}$ & 37,25 \\
\hline \multicolumn{3}{|l|}{ Usia } \\
\hline 1. Usia 20-29 tahun & 7 & 13,72 \\
\hline 2. Usia 30-39 tahun & 10 & 19,61 \\
\hline 3. Usia 40-49 tahun & 17 & 33,34 \\
\hline 4. Usia 50-59 tahun & 10 & 19,61 \\
\hline 5. Usia 60-69 tahun & $\begin{array}{c}7 \\
(\mathrm{n}=51 \text { dan } \bar{X} \\
=45)\end{array}$ & 13,72 \\
\hline
\end{tabular}

Pada Tabel 1 berdasarkan stadium didapatkan 15 pasien $(29,41 \%)$ stadium II, 10 pasien $(19,61 \%)$ stadium III, dan 26 pasien $(50,98 \%)$ stadium IV. Stadium IV menjadi stadium terbanyak yang dijumpai disebabkan karena letak anatomi nasofaring yang tersembunyi sehingga pasien baru merasakan atau mengeluhkan gejala pada saat tumor sudah meluas atau ada keluhan benjolan di leher yang mencolok.

Berdasarkan jenis kelamin didapatkan 32 pasien $(62,75 \%)$ berjenis kelamin laki-laki dan 19 pasien $(37,25 \%)$ berjenis kelamin perempuan. Perbandingan antara laki-laki dan perempuan adalah 1,68:1. Hal ini dapat disebabkan oleh faktor risiko terjadinya kanker nasofaring seperti pajanan asap rokok, zat kimia, dan karsinogen lainnya yang berkaitan dengan pekerjaan.

Berdasarkan usia, rerata usia sampel penelitian adalah 45 tahun. Tujuh pasien $(13,72 \%)$ berusia 20-29 tahun, 10 pasien $(19,61 \%)$ berusia $30-39$ tahun, 17 pasien $(33,34 \%)$ berusia $40-49$ tahun, 10 pasien $(19,61 \%)$ berusia 50-59 tahun, dan 7 pasien $(13,72 \%)$ berusia $60-69$ tahun. Terbanyak ditemukan pada pasien dengan puncak usia antara 40-49 tahun. Peristiwa ini dapat terjadi karena gaya hidup tidak sehat yang dimulai sejak usia remaja. Merokok, konsumsi alkohol dan konsumsi makanan atau minuman yang mengandung banyak bahan pengawet menyebabkan paparan bahanbahan karsinogenik yang dikemudian hari menyebabkan kanker nasofaring.

\section{Stadium}

Tabel 2. Perubahan Volume Tumor Berdasarkan Stadium $\begin{array}{llll}\text { Stadium } \mathrm{n} & \text { Volume } & \text { Volume } & \text { Perubahan } \\ \end{array}$ 


\begin{tabular}{lcccc}
\hline & & $\begin{array}{c}\text { Pre- } \\
\text { Radiasi }\end{array}$ & Post-Radiasi & Volume \\
Stadium II & 15 & 1741,75 & 46,13 & 206,56643 \\
Stadium III & 10 & 918,24 & 95,21 & 135,81397 \\
Stadium IV & 26 & 3179,38 & 623,97 & 168,83302 \\
\hline
\end{tabular}

Pada Tabel 2 dapat dilihat bahwa stadium II dengan jumlah sampel 15 pasien memiliki volume pre-radiasi total $1741,75 \mathrm{cc}$ dan volume postradiasi total $46,13 \mathrm{cc}$ sehingga didapat perubahan volume pada stadium II sebesar 206,56643cc.

Pada stadium III dengan jumlah sampel 10 pasien memiliki volume pre-radiasi total $918,24 \mathrm{cc}$ dan volume post-radiasi total 95,21cc sehingga didapat perubahan volume pada stadium III sebesar $135,81397 \mathrm{cc}$.

Pada stadium IV dengan jumlah sampel 26 pasien memiliki volume pre-radiasi total $3179,38 \mathrm{cc}$ dan volume post-radiasi total $623,97 \mathrm{cc}$ sehingga didapat perubahan volume pada stadium IV sebesar 168,83302cc.

Perubahan volume tumor stadium II menjadi yang paling besar mungkin terjadi karena tumor size (T) yang kecil. Sedangkan sebaran TNM pada stadium IV terbagi pada stadium IVA dan IVB. Pada stadium IVA yang terbanyak adalah T4N1 dan stadium IVB yang terbanyak adalah T2N3. Untuk penyinaran radiasi kanker nasofaring pada stadium IV, beberapa pasien selain mendapatkan kemoradiasi concurrent sebelumnya juga mendapatkan kemoterapi neoadjuvan.

Berdasarkan hal tersebut, meskipun tidak sepenuhnya sesuai dengan panduan pelayanan medik yang berlaku, namun pemberian kemoterapi neoadjuvan pada kelompok N0/1 masih dapat dimanfaatkan pada ukuran $\mathrm{T}$ yang ekstensif dengan tujuan memperkecil tumor primer. Maka kejadian tentang perubahan volume tumor pada stadium IV lebih besar dari stadium III kemungkinan disebabkan oleh induksi kemoterapi neoadjuvan.

\section{Jenis Kelamin}

Tabel 3. Perubahan Volume Tumor Berdasarkan Jenis

\begin{tabular}{|c|c|c|c|c|}
\hline \multicolumn{5}{|c|}{ Kelamin } \\
\hline $\begin{array}{c}\text { Jenis } \\
\text { Kelamin }\end{array}$ & $n$ & $\begin{array}{c}\text { Volume } \\
\text { Pre-- } \\
\text { Radiasi }\end{array}$ & $\begin{array}{l}\text { Volume } \\
\text { Post- } \\
\text { Radiasi }\end{array}$ & $\begin{array}{c}\text { Perubahan } \\
\text { Volume }\end{array}$ \\
\hline Laki-laki & 32 & 3650,10 & 464,40 & 174,18946 \\
\hline Perempuan & 19 & 2189,27 & 300,91 & 176,02196 \\
\hline
\end{tabular}

Pada Tabel 3 dapat dilihat dari jenis kelamin laki-laki dengan jumlah sampel 32 pasien memiliki volume pre-radiasi total $3650,10 \mathrm{cc}$ dan volume post-radiasi total $464,40 \mathrm{cc}$ sehingga didapat perubahan volume pada laki-laki sebesar 174,18946cc.

Sedangkan dari jenis kelamin perempuan dengan jumlah sampel 19 pasien memiliki volume pre-radiasi total $2189,27 \mathrm{cc}$ dan volume postradiasi total $300,91 \mathrm{cc}$ sehingga didapat perubahan volume pada perempuan sebesar 176,02196cc.

Hal ini sejalan dengan sebuah studi pada populasi Asia yang melakukan observasi bahwa pasien wanita lebih cenderung memiliki angka kesintasan yang lebih baik. Selain itu, kepustakaan juga menyebutkan bahwa prognosis diperburuk oleh beberapa faktor salah satunya adalah laki-laki dari pada perempuan, serta kemungkinan perempuan memiliki efek proteksi dari hormon estrogen.

Usia

Tabel 4. Perubahan Volume Tumor Berdasarkan Usia

\begin{tabular}{|c|c|c|c|c|}
\hline Usia & $\mathrm{n}$ & $\begin{array}{c}\text { Volume } \\
\text { Pre- } \\
\text { Radiasi }\end{array}$ & $\begin{array}{l}\text { Volume } \\
\text { Post-- } \\
\text { Radiasi }\end{array}$ & $\begin{array}{l}\text { Perubahan } \\
\text { Volume }\end{array}$ \\
\hline $\begin{array}{l}\text { Usia 20-39 } \\
\text { tahun }\end{array}$ & 17 & 1763,35 & 107,10 & 183,42215 \\
\hline $\begin{array}{l}\text { Usia } 40-49 \\
\text { tahun }\end{array}$ & 17 & 2054,21 & 307,19 & 175,36875 \\
\hline $\begin{array}{l}\text { Usia } \\
\text { tahun }\end{array}$ & 17 & 2021,81 & 351,02 & 166,95548 \\
\hline
\end{tabular}

Pada Tabel 4 dapat dilihat dari kelompok usia 20-39 tahun dengan jumlah sampel 17 pasien memiliki volume pre-radiasi total $1763,35 \mathrm{cc}$ dan volume post-radiasi total $107,10 \mathrm{cc}$ sehingga didapat perubahan volume pada kelompok usia 20 39 tahun sebesar $183,42215 \mathrm{cc}$.

Pada kelompok usia 40-49 tahun dengan jumlah sampel 17 pasien memiliki volume preradiasi total 2054,21cc dan volume post-radiasi total $307,19 \mathrm{cc}$ sehingga didapat perubahan volume pada kelompok usia 40-49 tahun sebesar 175,36875cc.

Pada kelompok usia $>50$ tahun dengan jumlah sampel 17 pasien memiliki volume pre-radiasi total 2021,81cc dan volume post-radiasi total $351,02 \mathrm{cc}$ sehingga didapat perubahan volume pada kelompok usia $>50$ tahun sebesar $166,95548 \mathrm{cc}$.

Perubahan volume tumor pada kelompok usia $>50$ tahun menjadi yang paling kecil. Hal ini dikaitkan bahwa penuaan dapat menjadi predisposisi kanker melalui beberapa mekanisme, yaitu akumulasi jaringan dari sel-sel pada tahap lanjut dari karsinogenesis, perubahan homeostasis khususnya perubahan pada sistem imun dan sistem endokrin, dan instabilitas telomer terkait penuaan dan peningkatan risiko kanker. 


\section{Respon Tumor}

\begin{tabular}{lcc}
\multicolumn{3}{c}{ Tabel 5. } \\
\hline \multicolumn{1}{c}{ Stadium } & Respon Tumor Berdasarkan Stadium \\
Stadium II & $15(29,42 \%)$ & Nonresponders $(-)$ \\
Stadium III & $9(17,65 \%)$ & 0 \\
Stadium IV & $24(47,05 \%)$ & $1(1,96 \%)$ \\
Total & $94,12 \%$ & $2(3,92 \%)$ \\
\hline
\end{tabular}

Berdasarkan Tabel 5 respon tumor pada stadium II sebanyak 15 pasien $(29,42 \%)$ masuk kategori responders (+) terdiri dari 13 pasien complete responses, 2 pasien partial response, dan tidak ada yang masuk pada kategori nonresponders (-). Namun respon tumor pada stadium III sebanyak 9 pasien $(17,65 \%)$ masuk kategori responders $(+) 7$ complete response dan 2 partial response, serta yang masuk pada kategori nonresponders (-) sebanyak 1 pasien $(1,96 \%)$ no change.

Sedangkan pada respon tumor di stadium IV sebanyak 24 pasien $(47,05 \%)$ yang masuk kategori responders $(+)$ terdiri dari 11 pasien complete response dan 13 pasien partial response, serta terdapat 2 pasien $(3,92 \%)$ no change yang masuk kategori nonresponders (-).

Tabel 6. Respon Tumor Berdasarkan Jenis Kelamin

\begin{tabular}{lcc}
\hline \multicolumn{1}{c}{ Jenis Kelamin } & Responders $(+)$ & $\begin{array}{c}\text { Nonresponders } \\
(-)\end{array}$ \\
Laki-laki & $30(58,82 \%)$ & $2(3,92 \%)$ \\
Perempuan & $18(35,30 \%)$ & $1(1,96 \%)$ \\
Total & $94,12 \%$ & $5,88 \%$ \\
\hline
\end{tabular}

Berdasarkan Tabel 6 respon tumor pada jenis kelamin laki-laki sebanyak 30 pasien $(58,82 \%)$ masuk dalam kategori responders (+) terdiri dari 20 pasien complete response, 10 pasien partial response, dan 2 pasien $(3,92 \%)$ no change yang masuk dalam kategori nonresponders (-). Sedangkan respon tumor pada jenis kelamin perempuan sebanyak 18 pasien $(35,30 \%)$ yang masuk dalam kategori responders (+) terdiri dari 11 pasien complete response, 7 pasien partial response, dan 1 pasien $(1,96 \%)$ no change dalam kategori nonresponders (-).

Tabel 7. Respon Tumor Berdasarkan Usia

\begin{tabular}{lcc}
\hline \multicolumn{1}{c}{ Usia } & Responders $(+)$ & Nonresponders $(-$ \\
Usia 20-39 & $17(33,34 \%)$ & 0 \\
tahun & & \\
Usia $40-49$ & $16(31,37 \%)$ & $1(1,96 \%)$ \\
tahun & & $2(3,92 \%)$ \\
Usia $>50$ tahun & $15(29,41 \%)$ & $5,88 \%$ \\
Total & $94,12 \%$ & \\
\hline
\end{tabular}

Berdasarkan Tabel 7 respon tumor pada kelompok usia 20-39 tahun sebanyak 17 pasien $(33,34 \%)$ masuk kategori responders (+) terdiri dari 11 pasien complete response, 6 pasien partial response, dan tidak ada yang masuk pada kategori nonresponders (-). Respon tumor pada kelompok usia 40-49 tahun sebanyak 16 pasien $(31,37 \%)$ masuk kategori responders $(+)$ terdiri dari 8 pasien complete response dan 8 pasien partial response, serta yang masuk pada kategori nonresponders (-) sebanyak 1 pasien $(1,96 \%)$ no change.

Sedangkan pada respon tumor di kelompok $>50$ tahun sebanyak 15 pasien $(29,41 \%)$ yang masuk kategori responders (+) terdiri dari 12 pasien complete response dan 3 pasien partial response, serta terdapat 2 pasien $(3,92 \%)$ no change masuk kategori nonresponders (-).

\section{Simpulan}

Respon tumor menurut kriteria WHO dibagi menjadi complete response, partial response, no change, dan progressive disease. Pada dua kategori pertama digabung dan didefinisikan menjadi responders (+) dan dua terakhir digabung dan didefinisikan menjadi nonresponders (-). Berdasarkan stadium (Tabel 5), jenis kelamin (Tabel 6), dan usia (Tabel 7), respon tumor terhadap radiasi pada kategori responders (+) sebesar 94,12\% dan kategori nonresponders (-) sebesar 5,88\%. Besarnya persentase kategori responders memberi kesan bahwa perubahan volume tumor mengarah pada keefektivitasan radiasi dan prognosis yang lebih baik serta respon tumor positif.

\section{Daftar Pustaka}

Ayu D, Ningrum R, Rahmawati T. Pengaruh Kemoterapi terhadap Asupan Makan dan Status Gizi Penderita Kanker Nasofaring. 2015;12:5866.

Brillian Putri E. Karakteristik Penderita Karsinoma Nasofaring di Departemen Ilmu Kesehatan THT-KL FKUP/RSUP DR.Hasan Sadikin Bandung Periode Tahun 2006-2010. Bandung; 2011.

Christanti J. Tingkat Ketahanan Hidup Pasien Kanker Nasofaring pada Berbagai Modalitas Terapi. 2011;1-17.

Kentjono WA. Perkembangan Terkini Penatalaksanaan Karsinoma Nasofaring. Maj Kedoteran Trop Indones. 2003;14:1-39.

Kurniawati D, Kuhuwael FG, Punagi AQ. Penilaian Kualitas Hidup Penderita Karsinoma Nasofaring 
Berdasarkan Karnofsky Scale, EORTC QLQC30 dan EORTC QLQ-H dan N35. 2013;43(2):110-20.

Lo KW, To KF, Huang DP. Focus on Nasopharyngeal Carcinoma. 2004;5:423-8.

Liu L, Tang L, Chen Q-Y, Zhang L, Guo S-S, Guo L, et al. The Prognostic Value of Plasma EpsteinBarr Viral DNA and Tumor Response to Neoadjuvant Chemotherapy in Advanced-Stage Nasopharyngeal Carcinoma. Radiat Oncol Biol [Internet]. 2015;93(4):862-9. Available from: http://dx.doi.org/10.1016/j.ijrobp.2015.08.003

Muin A. Analisis Profilaksis Itraconazole dan Faktorfaktor Lainnya Terhadap Kejadian Mukositis Oral Kandida Akibat Radioterapi pada Penderita Karsinoma Nasofaring. Semarang; 2009.

Nurmasari S, Samiadi D, Purwanto B. Pengaruh Radioterapi Eksternal Terhadap Fungsi Sel Rambut Luar Koklea Penderita Karsinoma Nasofaring. Vol. 42. 2007.

Rosita I, Widyaningsih S. Gambaran Tingkat Pengetahuan tentang Radioterapi pada Pasien Kanker Nasofaring di RSUD DR Moewardi Surakarta. Jur Keperawatan [Internet]. 2017; Available from: http://ejournal-s1.undip.ac.id/

Wang W, Lin T, Twu C, Tsou H, Lin P, Liu Y, et al. Long-Term Clinical Outcome in Nasopharyngeal Carcinoma Patients With PostRadiation Persistently Detectable Plasma EBV DNA. 2016;7(27).

Wijaya M, Djakaria M. Radioterapi \& Onkologi Indonesia. J Indones Radiat Oncol Soc. 2012;3(2):36-72.

Yarbro CH, Wujcik D, Gobel BH. Cancer Nursing Principle and Practice. Seventh. USA: Jones and Bartlett Publisher; 2011. 